Yol.2 2Nn. I لanuari 2019

ISSN 2614-2775

e-ISSN 2621-8143

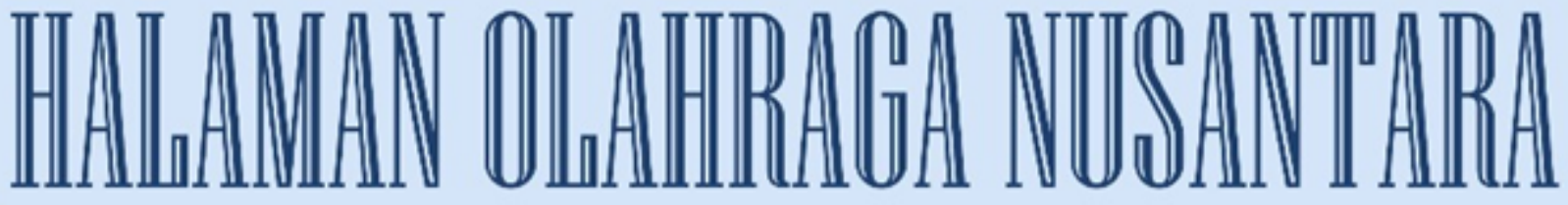

Surnal @lmu Xeolahragaan

Diterbitkan Oleh:

Program Studi Pendidikan Olahraga

Fakultas Keguruan dan Ilmu Pendidikan

Universitas PGRI Palembang

Jurnal

Volume Nomor Halaman Palembang ISSN/e-ISSN

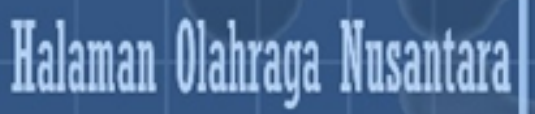

\begin{tabular}{l|l|l|l}
2 & 1 & $1-96$ & 2019
\end{tabular}




\section{Halaman Olahraga Nusantara}

Jurnal Ilmu Keolahragaan

Volume 2, Nomor 1, Januari 2019

Pelindung/Penasehat

Dr. H. Bukman Lian, M. M., M. Si.

Penanggung Jawab

Dr. Dessy Wardiah, M. Pd.

Ketua Dewan Redaksi

Farizal Imansyah, M. Pd.

Wakil Ketua Dewan Redaksi

Ilham Arvan Junaidi, M. Pd.

Sekretaris

Bayu Iswana, M. Pd.

Penyunting Pelaksana

Rafel Orlando, M. Pd.

Ardo Okilanda, M. Pd.

Daryono, M. Pd.

\section{Mitra Bestari}

Prof. Dr. A. Sofyan Hanif, M. Pd (Universitas Negeri Jakarta)

Dr. Sukirno (Universitas Sriwijaya)

Dr. Ronni Yenes, M. Pd (Universitas Negeri Padang)

Dr. Benny, M. Pd. (Universitas Negeri Makasar)

Dr. Putri Cicilia Kristina, M. Pd (Universitas PGRI Palembang)

\section{Tata Usaha}

M. Taheri Akbar, M. Pd.

Widya Handayani, S. Pd., M. Si.

Setting:

Dede Dwiansyah Putra, M. Pd.

Alamat Redaksi:

Prodi Pendidkan Olahraga Fakultas Keguruan Ilmu dan Pendidikan Universitas PGRI Palembang

Jl. Jendral A. Yani Lorong Gotong Royong 9/10 Ulu Palembang

Telp. 0711-510043, Fax. 0711-514782

e-mail jurnal: jurnalhonupgripalembang@gmail.com

e-mail : ardo.oku@univpgri-palembang.ac.id

website: univpgri-palembang.ac.id 
Halaman Olahraga Nusantara (Jurnal Ilmu Keolahragaan)

P-ISSN 2614-2775

Volume 2, No. 1, Januari 2019

E-ISSN 2621-8143

\section{DAFTAR ISI}

Hasil Penelitian

Halaman

Pengaruh Metode Rangkaian Bermain Terhadap Keterampilan Dasar Olahraga Panahan Siswa Ektrakulikuler Sit (Sekolah Islam Terpadu) Auladi Palembang

- Arisman

Penerapan Metode Bermain Dalam Meningkatkan Hasil Belajar Guling Depan (Forward Roll)

- Ruslan, M. Samsul Huda

Survei Tingkat Kesegaran Jasmani pada Peserta Ekstrakulikuler Sepakbola Di Sma Negeri 2 Oku

- Daryono

Kontribusi Daya Ledak Tungkai dan Keseimbangan Terhadap Kemampuan Lompat Jauh Murid Sd Negeri 139 Sinjai

- Adam Mappaompo

Survei Tingkat Kebugaran Jasmani Mahasiswa Pendidikan Olahraga Angkatan 2017 Stkip Pgri Bangkalan

- Heni Yuli Handayani .

Profil Delayed Onset Muscle Soreness (Doms) pada Mahasiswa Fik Unp Setelah Latihan Fisik

- Heru Syarli Lesmana

Perbedaan Pengaruh Latihan Menggunakan Karet dengan Menggunakan Dumbbell $1 \mathrm{Kg}$ Terhadap Kecepatan Pukulan Oi Tsuki

Chudan pada Atlet Karate Putra Perguruan Wadokai Dojo Sma Negeri 11 Medan Tahun 2017

- Pangondian Hotliber Purba $60-71$

Tinjauan Kondisi Fisik Atlet Sepakbola Kabupaten Kerinci Dalam

Rangka Persiapan Mengikuti Porprov Xxii Bungo Tebo 2018

- Palmizal, Wawan Junresti Daya, dan Sri Murniati

Aktivitas Jasmani dan Persepsi Gerak Anak Usia Dini

- Dian Pujianto 
Peningkatan Keterampilan Bermain Bolabasket Mahasiswa Melalui Latihan Aktifitas Maze Perkuliahan Permainan Bolabasket

- Ilham Arvan Junaidi dan Rury Rizhardy $88-96$ 


\title{
PROFIL DELAYED ONSET MUSCLE SORENESS (DOMS) PADA MAHASISWA FIK UNP SETELAH LATIHAN FISIK
}

\author{
Oleh: Heru Syarli Lesmana \\ (Dosen Univeristas Negeri Padang)
}

\begin{abstract}
Abstrak
Latihan fisik menyebabkan atlet beresiko mengalami cedera. Salah satu cedera otot yang paling sering dijumpai adalah Delayed Onset Muscle Soreness (DOMS). DOMS adalah nyeri yang dirasakan seseorang dalam waktu 24-72 jam setelah melakukan aktivitas olahraga. Tujuan penelitian ini adalah untuk melihat tingkat nyeri yang terjadi akibat DOMS setelah latihan fisik. Jenis penelitian ini adalah deskriptif kualitatif. Sampel merupakan Mahasiswa Fakultas Ilmu Keolahragaan Universitas Negeri Padang terdiri dari 15 orang mahasiswa dipilih secara random yang memenuhi kriteria inklusi diantaranya jenis kelamin laki-laki berumur 18-20 tahun, tidak mengalami cidera pada bagian tungkai ke bawah. Setiap Sampel akan melakukan latihan fisik eksentrik dengan jalan jongkok sebanyak 10 set (1set :20 langkah) dengan istirahat selama 30 detik setiap set. Setelah 48 jam, dilakukan pengukuran DOMS dengan menggunakan Visual Analog Scale (VAS). Data hasil penelitian ditabulasi dan dianalisis dengan uji statistik deskriptif. Kesimpulan penelitian setelah melakukan latihan fisik $26,7 \%$ sampel mengalami DOMS skala sedang dan 73,3\% sampel menderita DOMS skala berat terkontrol.
\end{abstract}

Kata Kunci: Delayed Onset Muscle Soreness (DOMS), Latihan Fisik, Universitas Negeri Padang

\section{DELAYED ONSET MUSCLE SORENESS (DOMS) PROFILE AT PADANG STATE UNIVERSITY STUDENT}

\begin{abstract}
Physical exercise causes athletes at risk of injury. One of the most common muscle injuries is Delayed Onset Muscle Soreness (DOMS). DOMS is pain that is felt by someone within 24-72 hours after doing sports activities. The purpose of this study was to see the level of pain that occurs due to DOMS after physical exercise. This type of research is qualitative descriptive. The sample consisted of 15 students from the Faculty of Sport Science, Padang State University, randomly selected who met the inclusion criteria, including male sex aged 18-20 years, not having injuries to the lower limbs. Each sample did eccentric physical exercise by squatting as much as 10 sets (1set: 20 steps) and taken a rest for 30 seconds each set. After 48 hours, DOMS measurements were performed using the Visual Analog Scale (VAS). Data from the research were tabulated and analyzed by descriptive statistical tests. Conclusion of the study after doing physical exercise $26.7 \%$ of the samples experienced moderate-scale DOMS and $73.3 \%$ of the samples had controlled heavy-scale DOMS.
\end{abstract}


Keywords: Delayed Onset Muscle Soreness (DOMS), Physical Exercise, Padang State University

\section{A. PENDAHULUAN}

Prestasi terbaik altet merupakan hasil dari pembinaan yang diberikan kepada atlet melalui latihan-latihan yang terprogram dengan baik dan terarah. Pembinaan dalam olahraga adalah usaha sadar yang dilakukan secara sistematis untuk mencapai tujuan keolahragaan. Dalam pembinaan olahraga sudah jelas prestasi menjadi tujuan utama. Pembinaan yang dilakukan tersebut salah satunya melalui latihan, karena menurut Harsono (1996) bahwa; "tujuan latihan adalah untuk membantu atlet meningkatkan keterampilan dan prestasinya terutama terhadap empat aspek seperti; teknik, kondisi fisik, taktik dan strategi, serta mental". Apabila salah satu dari aspek tersebut lemah, maka akan berpengaruh terhadap aspek yang lain, sehingga berakibat atlet tidak bisa tampil maksimal dalam setiap pertandingan.

Latihan merupakan suatu proses yang sistematis atau pekerjaan yang dilakukan berulang-ulang dalam jangka waktu yang cukup lama dengan meningkatkan beban latihan secara bertahap dan memiliki sifat individu. Setiap rangkaian gerakan pada latihan didesain untuk meningkatkan kemampuan dengan melibatkan pembangkitan tenaga dan aktivitas otot serta melakukan adaptasi terhadap stimulasi yang berulang (Fox, 1993). Rangkaian gerakan yang terus meningkat pada latihan fisik menyebabkan atlet beresiko mengalami cedera. Cedera olahraga merupakan segala bentuk kegiatan melewati batas ambang kemampuan tubuh sebagai akibat berolahraga. Secara fisiologi cedera olahraga terjadi akibat ketidak seimbangan antara beban kerja dengan kemampuan jaringan tubuh yang melakukan aktivitas olahraga. Pada umumnya penyebab terjadinya cedera olahraga antara lain karena kurang pemanasan, melakukan teknik seperti smash yang salah, memaksakan kondisi tubuh melewati batas ambang kemampuan tubuh sebelum berolahraga terutama pada jelang latihan yang menuntut banyak gerakan eksplosif (Hardianto Wibowo 1995). Salah satu jenis cedera yang sering terjadi pada atlet adalah cedera otot. 
Cedera otot, menurut US Department of Labor, Bureau of Labor Statistic pada tahun 2001 mempunyai angka kejadian sebesar 76,5\%. Salah satu cedera otot yang paling sering dijumpai adalah Delayed Onset Muscle Soreness (DOMS). DOMS adalah nyeri yang dirasakan seseorang dalam waktu 24-72 jam setelah melakukan aktivitas olahraga. DOMS menimbulkan kekakuan, bengkak, penurunan kekuatan dan nyeri pada otot. DOMS disadari dengan adanya rasa nyeri yang didapati 12-24 jam setelah olahraga dan memuncak dalam waktu 2448 jam setelah olahraga (Szymanski, 2003). Muscle soreness terjadi ketika muscle fiber mengalami robekan, dan otot beradaptasi untuk menjaga kekuatannya. Tingkat kerusakan dan nyeri dapat disebabkan beberapa faktor misalnya pada tingkat profesional dapat disebabkan karena dosis latihan dan intensitas dari latihan yang diberikan. Bila pada seseorang yang bukan atlet kerusakan dapat disebabkan karena aktifitas otot melebihi dari kemampuan dlm melakukan aktifitas dan gerakan yang salah. Muscle soreness dapat menyebabkan rasa tidak nyaman atau nyeri yang kadang kita tidak mengetahui penyebab nyeri tersebut dapat timbul (Cheung et al., 2003).

Delayed Onset Muscle Soreness (DOMS) selalu dikaitkan dengan keadaan yang tidak biasa, kerja otot yang berlebihan dan kontraksi eksentrik dapat memicu terjadinya DOMS. Kontraksi otot eksentrik dapat dilihat dari adanya perpanjangan otot selama otot berkontraksi. Mekanisme terjadinya DOMS dapat dikaitkan dengan adanya stimulasi nyeri yang disebabkan dengan adanya pembentukan asam laktat, kekakuan otot, kerusakan jaringan ikat, kerusakan otot, peradangan. Gejala yang bisa muncul dalam 24 - 42 jam setelah latihan dan bisa menghilang setelah 5 - 7 hari ( Cheung et al., 2003).

Dalam penelitian disebutkan bahwa DOMS dapat terjadi pada saat kita melakukan aktifitas lari gunung (Hiking), Ressisted Cycling, Stepping, ballistic stretching, isocinetic dynamometri, dan latihan melawan tahanan. Delayed Onset Muscle Soreness (DOMS) dapat diklasifikasikan sebagai cedera pada otot tipe I dan dapat diketahui dengan adanya nyeri tekan dan spasme pada saat dilakukan palpasi dan gerakan. Nyeri tekan dapat terlokalisasi pada bagian distal otot dan dapat bertambah nyeri dalam waktu $24-48$ jam setelah melakukan latihan. Rasa 
nyeri tersebut dapat menggambarkan tingginya receptor pada jaringan lunak dan pada tendon otot. Beberapa penelitian melakukan kombinasi beberapa tekhnik untuk dapat memberikan penanganan pada DOMS seperti warm up, stretching dan massage, warm underwater water jet massage dan ice massage. Rasa nyeri dan kerusakan pada otot dapat terjadi karena melakukan latihan yang bersifat kontinyu atau terus menerus (Connoly et al., 2003)Latihan eksentrik merupakan salah satu model latihan berdasarkan jenis kontraksi otot. Selain latihan eksentrik, terdapat latihan isometrik. Latihan isometrik merupakan latihan yang ototnya mengalami kontraksi yang isometrik, artinya tidak terlihat adanya gerakan. Pada kontraksi isometrik, jembatan persilangan (Cross Bridges) membangkitkan kekuatan tetapi tidak menggerakkan filamen, sehingga tidak merubah pola ikatan kepala miosin kepada aktin dari kedaan istirahat. Pada latihan eksentrik, kontraksi menyebabkan jembatan silang miosin melekat dan protein aktin saling menjauh sehingga terjadi pemanjangan sarkomer. Pada kontraksi eksentrik, otot memanjang, karena diregangkan oleh suatu gaya eksternal selagi berkontraksi (Sherwood, 2011; Wilmore, 1994). Ada dua istilah latihan yaitu acute exercise (latihan yang bersifat akut) dan chronic exercise (latihan yang bersifat kronik).

Acute exercise adalah latihan yang dilakukan hanya sekali saja atau disebut juga dengan exercise, sedangkan chronic exercise adalah latihan yang dilakukan berulang-ulang sampai beberapa hari atau sampai beberapa bulan atau biasa disebut training (McArdle, 2010). Perubahan yang terjadi pada waktu seseorang melakukan exercise disebut dengan respon. Latihan fisik sebaiknya dilakukan sesuai dengan kemampuan tubuh dalam menanggapi stres yang diberikan, bila tubuh diberi beban latihan yang terlalu ringan maka tidak akan terjadi proses adaptasi. Tubuh tidak akan bisa mentolerir jika beban latihan yang diberikan terlalu berat sehingga dapat menyebabkan terganggunya proses homeostasis pada sistem tubuh dan dapat mengakibatkan kerusakan. Salah satu yang sering mengalami kerusakan akibat latihan fisik adalah otot. Kerusakan otot mengakibatkan otot mengalami cedera. Delayed Onset Muscle Soreness (DOMS) adalah cedera otot yang sering terjadi akibat latihan. 


\section{B. METODE PENELITIAN}

Jenis penelitian yang digunakan dalam penelitian ini adalah deskriptif kualitatif. Sampel merupakan Mahasiswa Fakultas Ilmu Keolahragaan Universitas Negeri Padang yang memenuhi kriteria inklusi diantaranya jenis kelamin laki-laki berumur 18-20 tahun, tidak mengalami cidera pada bagian tungkai ke bawah, memiliki cidera yang diperberat dengan olahraga, dan yang mengkonsumsi obatobatan anti inflamasi pada saat penelitian dilakukan bestatus sehat dibuktikan dengan mengukur denyut nadi, tensi dan menggunakan PAR-Q. 45 sampel terdiri dari 15 orang mahasiswa. Setiap Sampel akan melakukan latihan fisik eksentrik dengan jalan jongkok sebanyak 10 set (1set :20 langkah) dengan istirahat selama 30 detik setiap set. Setelah 48 jam, dilakukan pengukuran DOMS dengan Visual Analog Scale (VAS). Data hasil penelitian ditabulasi dan dianalisis dengan uji statistik deskriptif.

\section{HASIL PENELITIAN DAN PEMBAHASAN}

Sesuai dengan rancangan analisis data, langkah awal analisis akan dimulai dengan melakukan analisa statistik deskriptif yang bertujuan untuk memperoleh gambaran distribusi dan untuk peringkasan data guna penyajian hasil. Data penelitian yang diperoleh meliputi data tingkat rasa nyeri, dan lokasi nyeri.

\section{Gambar 1. Grafik Lokasi Nyeri Sampel}

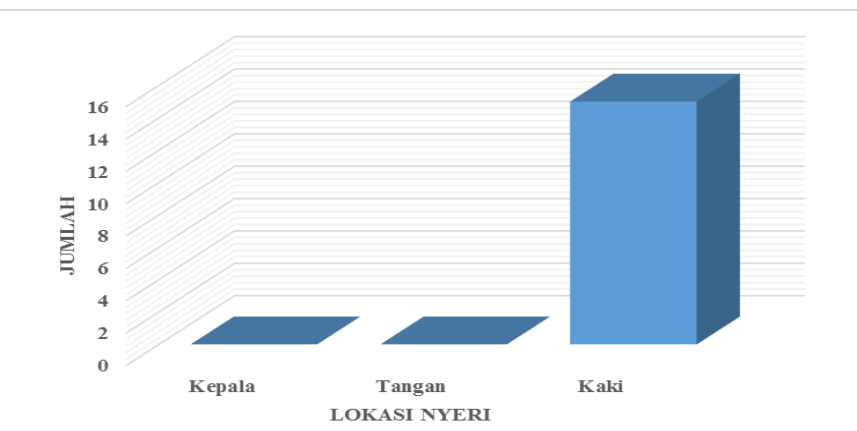

Hasil uji statistik deskriptif untuk tingkat rasa nyeri sedang diderita oleh 4 orang sampel dengan presentase 26, 67, tingkat berat terkendali diderita oleh 11 orang sampel dengan persentase 73,33. Semetara itu tidak ada sampel yang tidak mengalami rasa nyeri, nyeri ringan dan nyeri berat tidak terkendali setelah latihan fisik yang diberikan. 
Tabel 1 Hasil Deskriptif Penelitian

\begin{tabular}{clcc}
\hline Skala nyeri & \multicolumn{1}{c}{ Kategori } & Frekuensi & pesentase \\
\hline 0 & Tidak Nyeri & 0 & 0 \\
\hline $1-3$ & Nyeri Ringan & 0 & 0 \\
\hline $4-6$ & Nyeri Sedang & 4 & 26,67 \\
\hline $7-9$ & Nyeri Berat Terkontrol & 11 & 73,33 \\
\hline 10 & $\begin{array}{l}\text { Nyeri Berat Tidak } \\
\text { Terkontrol }\end{array}$ & 0 & 0 \\
\hline & Jumlah & \multicolumn{2}{c}{15} \\
\hline
\end{tabular}

Penelitian bertujuan mengetahui tingkat gejaya Delayed Omset Muscel Soreness (DOMS) yang dialami setelah latihan fisik. Latihan fisik diberikan pada sampel untuk menstimulus terjadinya DOMS. Sebelum melakukan latihan fisik dilakukan upaya mengetahui status kesehatan sempel dengan mengukur tensi, denyut nadi, dan Angket PAR-Q. Tensi dan denyut nadi diukur menggunakan tensimeter digital Omron. Latihan fisik yang dilakukan merupakan kegiatan latihan eksentrik dengan jalan jongkok sebanyak 8 set (1set :18 langkah) dengan istirahat selama 30 detik setiap set (Tanjung, JR, 2015). Setelah melakukan latihan fisik sampel diberikan arahan agar tidak melakukan aktivitas fisik yang berat selama 2 hari. Setelah 2 hari sampel dikumpulkan untuk dilakukan pengukuran DOMS dengan mengukur skala nyeri menggunakan Visual Analog Scale (VAS). VAS adalah Metode yang biasa digunakan untuk mengukur nyeri di klinik dan rumahsakit adalah skala visual analog. Skala ini berisi sebelas angka 0-10 yang menggambarkan kondisi tidak nyeri sampai nyeri yang berat (Raylene, 2008).

Cedera atau luka adalah sesuatu kerusakan pada struktur atau fungsi tubuh yang dikarenakan suatu paksaan atau tekanan fisik maupun kimiawi. Cedera adalah suatu akibat daripada gaya-gaya yang bekerja pada tubuh atau sebagian daripada tubuh dimana melampaui kemampuan tubuh untuk mengatasinya, gayagaya ini bisa berlangsung dengan cepat atau jangka lama (Afriwardi, 2009:34) 
Cedera olahraga merupakan segala bentuk kegiatan melampaui batas ambang kemampuan tubuh sebagai akibat berolahraga. Secara fisiologi cedera olahraga terjadi akibat ketidak seimbangan antara beban kerja dengan kemampuan jaringan tubuh yang melakukan aktivitas olahraga. Pada umumnya penyebab terjadinya cedera olahraga antara lain karena kurang pemanasan, melakukan teknik seperti smash yang salah, memaksakan kondisi tubuh melampaui batas ambang kemampuan tubuh sebelum berolahraga terutama pada jelang latihan yang menuntut banyak gerakan eksplosif (Hardianto Wibowo 1995: 22).

Delayed Onset Muscle Soreness (DOMS) merupakan jenis cedera yang sering terjadi setelah latihan fisik. Muscle soreness terjadi ketika muscle fiber mengalami robekan, dan otot beradaptasi untuk menjaga kekuatannya. Tingkat kerusakan dan nyeri dapat disebabkan beberapa faktor misalnya pada tingkat profesional dapat disebabkan karena dosis latihan dan intensitas dari latihan yang diberikan. Bila pada seseorang yang bukan atlet kerusakan dapat disebabkan karena aktifitas otot melebihi dari kemampuan dalam melakukan aktifitas dan gerakan yang salah. Muscle soreness dapat menyebabkan rasa tidak nyaman atau nyeri yang kadang kita tidak mengetahui penyebab nyeri tersebut dapat timbul (Cheung et al., 2003).

Cedera olahraga seringkali direspon oleh tubuh dengan tanda radang yang terdiri atas rubor (merah), tumor (bengkak), kalor (panas), dolor (nyeri), dan functiolaesa (penurunan fungsi). Pembuluh darah di lokasi cedera akan melebar (vasodilatasi) dengan maksud untuk mengirim lebih banyak nutrisi dan oksigen dalam rangka mendukung penyembuhan. Pelebaran pembuluh darah ini lah yang mengakibatkan lokasi cedera terlihat lebih merah (rubor). Seiring mengembangnya pembuluh darah akan terjadi pula perubahan permeabilitasnya, sehingga komponen tertentu di dalam darah seperti plasma darah dan sel dapat keluar dari pembuluh menuju daerah cedera tersebut. Hal ini merupakan proses yang baik bagi tubuh, karena leukosit akan mudah keluar dan menuju pusat cedera dan menyembuhkan serta meregenerasi sel yang rusak (Pfeifer, 2009).

Cairan darah yang banyak dikirim di lokasi cedera akan merembes keluar dari kapiler menuju ruang antar sel, dan menyebabkan bengkak (tumor). Dengan 
dukungan banyak nutrisi dan oksigen, metabolisme di lokasi cedera akan meningkat dengan sisa metabolisme berupa panas. Kondisi inilah yang menyebabkan lokasi cedera akan lebih panas (kalor) dibanding dengan lokasi lain. Tumpukan sisa metabolisme dan zat kimia lain akan merangsang ujung saraf di lokasi cedera dan menimbulkan nyeri (dolor). Rasa nyeri juga dipicu oleh tertekannya ujung saraf karena pembengkakan yang terjadi di lokasi cedera. Baik rubor, tumor, kalor, maupun dolor akan menurunkan fungsi organ atau sendi di lokasi cedera yang dikenal dengan istilah functiolaesa (Pfeifer, 2009). Dengan demikian semakin luas bagian yang mengalami cedera semakin besar tingkat rasa nyeri yang disarakan. Sehingga dapat disimpulkan latihan fisik dapat menyebabkan terjadinya gejala DOMS.

Nyeri menurut The Internasional Association for Study of Pain (IASP) adalah suatu pengalaman sensori dan emosional yang tidak menyenangkan, yang berhubungan dengan kerusakan jaringan secara aktual atau potensial. Derajat nyeri dan respon nyeri dapat berbeda pada setiap orang dikarenakan beberapa faktor diantaranya, umur, jenis kelamin, kecemasan, kultur, perhatian, pengalaman masa lalu, pola koping, dukungan keluarga dan sosial (Tamsuri, 2007). Umur dan jenis kelamin merupakan variabel yang dikendalikan dalam penelitian ini, umur sampel 18-20 tahun dan jenis kelamin laki-laki. Namun peneliti tidak mengendalikan faktor-faktor yang lain sehingga berkemungkinan menjadi faktor yang menentukan tingkat rasa nyeri yang diderita sampel.

Nyeri akibat DOMS yang terjadi setelah latihan fisik dapat dikurangi atau di hindari dengan melalukan proses latihan yang benar, diantaranya melalukan pendinginan dapat meringankan gejala DOMS dan melalukan pemulihan dengan recovery aktif (Lesmana HS, 2017). Penelitian juga sudah membuktikan berendam di air dingin setelah latihan fisik dapat meringankan gejala DOMS (Rakasiwi, 2013).

\section{KESIMPULAN}

Latihan fisik setelah melakukan latihan fisik 26,7\% sampel mengalami DOMS skala sedang dan 73,3\% sampel menderita DOMS skala berat terkontrol. 


\section{DAFTAR PUSTAKA}

Bompa TO. 1994. Theory and metodology of training, the key to athletic performance $3^{r d}$ ed. Lowa: Hunt Publising Company.

Cheung K, Hume PA, Maxwell L.2003. Delayed Onset Muscle Soreness Treatment Strategies And Performance Factors. Sports med 2003;33(2)145-164.

Connolly D, Sayers P, Mc Hugh P.2003. Treatment And Prevention Of Delayed Onset Muscle Soreness. Journal Of Strength And Conditioning Research,17(1),197-208

Donald Ary., Luchy C.Jacobs dan Asghar R, 2004. Pengantar Penelitian dalam Pendidikan, Yogyakarta: Pustaka Pelajar offset.

Fox EL. 1993. The physiological basis exercise and sport $5^{\text {th }}$ ed. USA: MW. Crown Communication.

Harsono. Prinsip dan Metodologi Pelatihan, Jakarta: PIO-KONI Pusat,1996.

Lesmana HS, Padli, Broto EP, 2017. Pengaruh Recovery Aktif dan Pasif dalam Meringankan Gejala Delayed Muscle Soreness (DOMS). Journal of Sport Science and Education. 2(2): 38-41.

Mc Ardle WD, Katch FI and Katch VL, 2010. Exercise Physiology : Energy, Nutrion and Human Performance. $2^{\text {nd }}$ ed. USA : Lea \& Febiger Philadelphia.

McAinch A.J, Febraio M.A, Parkin, Zhaou S. 2004. Effect of Active Versus Passive Recovery on Metabolism and Performance During Subsequent Exercise. International Journal of Sport Nutrition and Exercise Metabolism:14, 185-198.

Pemerintah RI. (2006). Undang-Undang no. 3 Tahun 2005 tentang Sistem Keolahragaan Nasional. Jakarta: Pusat Info Data Indonesia (PIDI)

Pfeiffer R.P, Thygerson A, Palmieri N.F. 2012. Pertolongan Pertama dan Pencegahan Cedera Olahraga-Terjemahan. Jakarta: Erlangga.

Priyatno D. 2016. Belajar Alat Ananlisis Data dan Cara Pengolahannya dengan SPSS. Yogyakarta: Gava Media 
Rakasiwi, Agung Mahaswara, 2013. Aplikasi Ice Massage Sesudah Pelatihan Lebih Baik dalam Mengurangi Terjadinya Delayed Onset Muscle Soreness daripada Tanpa Ice Massage pada Otot Hamstring (Tesis). Denpasar: Universitas Udayana.

Setiawan, Arief. 2011. Pengaruh recovery aktif dan recovery pasif terhadap penurunan kadar CK (enzyme creatine kinase) pada Cabang Atletik Nomor Lari Jarak Jauh DKI Jakarta. http://ariefsetiawan80.blogspot.com/2011/02/judul-penelitian.html, diakses pada 20Mai 2015

Sherwood L, 2011. Human physiology from cell to systems $6^{\text {th }}$ ed. Canada: Cengange Learning.

Spencer M, Bishop D, Dawnson, Goodman and Duffield. 2006. Metabolism and Performance in Repeated Cycle Sprints: Active versus Passive Recovery. Medicine \& Science In Sports \& Exercise. 1492-1499

Szymanski, D.J. 2003.Recommendations for the avoidance of delayed-onset muscle soreness. J. Strength Cond. Res. 23(4): 7-13.

Tamsuri A, 2007, Konsep dan Penatalaksanaan Nyeri. Jakarta:EGC

Tanjung JR, Pranoto TG, Prastowo NA, 2015. Pengaruh Pendinginan dalam Meringankan Gejala Delayed Onset Muscle Soreness (DOMS) Pada Mahasiswa FK Atma Jaya. Prosiding IAIFI XXIV. Padang

Wibowo, Hardianto. 1995. Pencegahan dan Petatalaksanaan Cedera Olahraga. Cetakan 1. Jakarta: EGC.

Wilmore J.H, Costill D.L, 1994. Physioly of Sport and Exercise. USA: Human Kinetic. 


\section{GAYA SELINGKUNG}

1. Jurnal Halaman Olahraga Nusantara menerbitkan karya ilmiah dan hasil penelitian dalam seluruh kajian ilmu keolahragaan, baik pendidikan, kepelatihan, dan lainya dalam pengembangan teori dan konsep yang belum pernah dipublikasikan. Jurnal ini memuat (1) kumpulan informasi baru, (2) hasil objektif dari suatu kajian ilmu keolahragaan, dan (3) rekomendasi.

2. Penulisan naskah menggunakan bahasa Indonesia secara benar. Panjang naskah antara 7-20 halaman, kertas ukuran quarto, diketik 1,5 spasi, tipe huruf Times New Roman, ukuran huruf 12, margin atas dan kiri 4 cm, kanan dan bawah $3 \mathrm{~cm}$.

3. Naskah ditulis dengan sistematika dan ketentuan sebagai berikut.

a. Judul: ditulis dengan singkat, padat, terdiri dari 5-15 kata, dan menggunakan bahasa Indonesia, harus mencerminkan substansi keilmuan yang diuraikan pada batang tubuh artikel. Judul utama (main title) dan anak judul (subtitle) dipisahkan dengan dua titik. Judul artikel dicetak 15 mm dibawah tepi atas, dengan huruf capital-kecil tebal. Judul subbab peringkat 1 dicetak capital semua, rata tepi kiri, tebal, peringkat 2 dicetak capital kecil, rata tepi kiri, tebal; peringkat 3 dicetak kapital-kecil, rata tepi kiri, miring-tebal.

b. Nama penulis: Nama penulis artikel ditulis tanpa disertai gelar akademik atau gelar apapun. Nama lengkap dengan gelar akademik boleh ditulis disebelah bawah halaman pertama artikel. Nama lembaga tempat bekerja penulis juga dibuat sebagai catatan kaki dihalaman pertama. Jika lebih dari tiga penulis, hanya penulis utama saja yang dicantumkan dibawah judul; nama penulis lain ditulis dalam catatan kaki.

c. Abstrak artikel kajian ilmiah/ konseptual adalah ringkasan dari isi artikel yang dituangkan secara padat menggunakan bahasa Indonesia dan bahasa inggris. Abstrak hasil penelitian memuat masalah atau tujuan, metode, dan hasil penelitian. Abstrak terdiri dari 100-300 kata yang disusun dalam satu 
paragraph dengan format esei bukan enumeratif, dan diketik dengan spasi tunggal serta dengan format yang lebih sempit dari teks utama.

d. Kata Kunci terdiri dari 3-5 kata, yaitu istilah-istilah yang mewakili ide atau konsep dasar yang dibahas dalam penulisan karya ilmiah. Kata kunci lazimnya berupa kata dasar atau kata yang berdiri sendiri (tunggal) bukan rangkaian kata.

e. Naskah hasil penulisan ditulis dengan urutan (1) judul, (2) nama penulis, (3) abstrak, (4) kata kunci, (5) bagian pendahuluan yang harus di akhiri dengan rumusan singkat (1-2 kalimat) tentang hal-hal pokok yang akan dibahas dan tujuan dari pembahasan. Untuk artikel hasil penelitian berisi (a) rumusan masalah, (b) tujuan, dan (c) deskripsi singkat mengenai kerangka pemikiran dalam pendahuluan, (6) isi memuat (a) metode penelitian, (b) hasil penelitian, dan (c) pembahasan. (8) simpulan dan saran, (9) daftar pustaka.

f. Naskah diluar hasil penelitian ditulis dengan urutan (1) judul, (2) nama penulis, (3) abstrak, (4) kata kunci, (5) pendahuluan yang memuat latar belakang dan rumusan masalah, (6) isi, (7) simpulan, dan (8) daftar pustaka.

g. Table dan gambar/ bagan di usahakan dicetak dalam satu halaman, nomor dan judul table dan gambar dicetak di atas table dengan huruf tebal. Isi dalam table dicetak dengan huruf normal (tidak tebal). Table hanya menggunakan garis horizontal (horizontal border)

h. Penulisan daftar pustaka

1) Buku ditulis dengan urutan: (a) nama akhir, (b) koma, (c) nama depan penulis, (d) titik, (e) tahun penerbitan, (f) titik, (g) judul buku dalam huruf miring, (h) titik, (i) edisi jika ada, (j) titik, (k) kota penerbitan, (l) titik dua, (m) nama penerbit, dan (n) titik.

2) Artikel ditulis dengan urutan: (a) nama akhir, (b) koma, (c) nama depan penulis, (d) titik, (e) tahun penerbitan, (f) titik, (g) tanda petik dua, (h) judul artikel, (i) titik, (j) tanda petik tutup, (k) nama jurnal dalam cetak miring, (l) volume, (m) nomor, dan (n) titik. Apabila artikel diterbitkan 
disuatu buku, tulis kata "dalam" sebelum nama editor buku tersebut, dan buku harus ditulis didalam daftar pustaka.

3) Skripsi, thesis, atau disertasi ditulis dengan urutan: (a) nama akhir, (b) koma, (c) nama depan penulis, (d) titik, (e) tahun, (f) titik, (g) judul dalam huruf miring, (h) skripsi/thesis/disertasi pada (nama perguruan tinggi yang bersangkutan), (i) nama kota, (j) titik dua, (k) tulisan "tidak diterbitkan", dan (1) titik. 